\title{
Expression of Platelet-derived Growth Factor (PDGF)-related Transcripts and Synthesis of Biologically Active PDGF-like Proteins by Human Malignant Epithelial Cell Lines
}

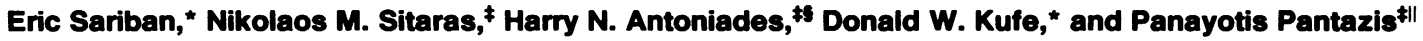 \\ * Laboratory of Clinical Pharmacology, Dana-Farber Cancer Institute, Harvard Medical School, Boston, Massachusetts 02115; \\ ${ }^{\ddagger}$ Department of Nutrition, Harvard School of Public Health, Boston, Massachusetts 02115; \$The Center for Blood Research, \\ Boston, Massachusetts 02115; and "Boston University School of Medicine, Boston, Massachusetts 02118
}

\begin{abstract}
Human malignant epithelial cell lines were analyzed for expression of platelet-derived growth factor (PDGF) genes. Of the 12 cell lines tested, 9, derived from breast, lung, gastric, and ovarian carcinomas, were found to express both PDGF-1 and PDGF-2 genes. The levels of both PDGF-1 and PDGF-2 transcripts were superinduced when these cells were treated with cycloheximide, an inhibitor of protein synthesis. These cells also released an activity that in studies with BALB-c/3T3 cells, inhibited binding of ${ }^{125} \mathrm{I}$-labeled PDGF and stimulated incorporation of $\left.{ }^{3} \mathrm{H}\right]$ thymidine. This stimulating activity was inhibited after reduction of the conditioned media by mercaptoethanol or after preincubation with antibodies to PDGF. Moreover, this activity was not affected by heat treatment. Immunoprecipitation studies revealed that breast, lung, and gastric carcinoma cells produced PDGF-like proteins that migrated as 30- and 32-kD species under nonreducing conditions and as 15- and 16-kD species under reducing conditions. In contrast, malignant cells of ovarian origin produced 14-16-kD PDGF-like proteins that were unchanged in mobility after reduction. As PDGF receptors were not detected on these malignant epithelial cells, the production of PDGF-like proteins may affect other cells in the microenvironment by paracrine mechanisms and may contribute to excessive cell proliferation, inflammatory reactions, and connective tissue remodeling seen in certain carcinomas.
\end{abstract}

\section{Introduction}

Platelet-derived growth factor (PDGF), ${ }^{1}$ a potent mitogen for cells of mesenchymal origin, is released from human blood platelets upon their degranulation (for review, see references 1 and 2). It consists of two polypeptide chains, PDGF-1 (or PDGF-A) and PDGF-2 (or PDGF-B), linked by disulfide

Address reprint requests to Dr. Donald Kufe, Laboratory of Clinical Pharmacology, Dana-Farber Cancer Institute, 44 Binney Street, Boston MA 02115. 1988.

Received for publication 22 June 1987 and in revised form 9 June

1. Abbreviations used in this paper: $\mathrm{CHX}$, cycloheximide; $\mathrm{CM}$, cellconditioned media; HTLV, human T cell lymphotropic virus; PDGF, platelet-derived growth factor.

J. Clin. Invest.

(c) The American Society for Clinical Investigation, Inc. $0021-9738 / 88 / 10 / 1157 / 08 \quad \$ 2.00$

Volume 82, October 1988, 1157-1164 bonds and encoded by two different genes located on chromosomes 7 and 22, respectively (3-5). The PDGF-1 and PDGF-2 genes code for precursor polypeptides whose predicted amino acid sequences have an overall $40 \%$ homology, while there is a $56 \%$ homology between the two mature PDGF chains (5). The PDGF-2 chain is very similar structurally, antigenically, and functionally to the p28 $8^{\text {sis }}$ transforming protein of the simian sarcoma virus (6). Whereas human PDGF is believed to be a heterodimer $(7,8)$, the PDGF-like protein produced by the human osteosarcoma U2OS cell line is a homodimer of PDGF-1 chains (9). The 30-32-kD authentic PDGF protein has mitogenic and chemotactic activity $(1,2)$, is a potent vasoconstrictor (10), and stimulates synthesis of both matrix components (11) and enzymes that degrade this matrix $(12,13)$.

PDGF-like proteins have been detected in endothelial cells $(14,15)$, vascular smooth muscle cells (16), and cytotrophoblasts (17). However, human plasma contains undetectable levels of PDGF. The ability of target cells to be activated by PDGF thus depends on local secretion and thereby on the anatomical location of cells producing PDGF. PDGF-like proteins also have been detected in several human malignant cell lines of mesenchymal origin (18-20) that also possess PDGF receptors (19). This finding has raised the possibility that autocrine stimulation of these cells could contribute to the transformed state and the development of automitogenic cell populations (19).

In this communication, we report that PDGF-1 and PDGF-2 mRNAs are expressed in human malignant epithelial cells of breast, ovary, lung, and gastric origin. Malignant breast, lung, and gastric cells produce 30-32-kD PDGF-like proteins that are similar in molecular weight to authentic PDGF and PDGF-like proteins detected in transformed human cell lines of mesenchymal origin. In contrast, malignant cells of ovarian origin produce 14-16-kD PDGF-like proteins that are similar in molecular weight to those detected in activated human macrophages. Furthermore, we demonstrate that the PDGF-like species secreted by malignant epithelial cells are biologically active.

As PDGF receptors were undetectable in malignant epithelial cells, these results suggest that PDGF-like proteins produced by these cells act through a paracrine mechanism. This mechanism may represent a way whereby malignant epithelial cells interact with and modulate their microenvironment.

\section{Methods}

Cells. The human epithelial cell lines used in this study included: four ovarian carcinoma cell lines (ARM, DUN, MAC, and SAM); three breast carcinoma cell lines (MCF-7, BT-20, and ZR75-1); two 


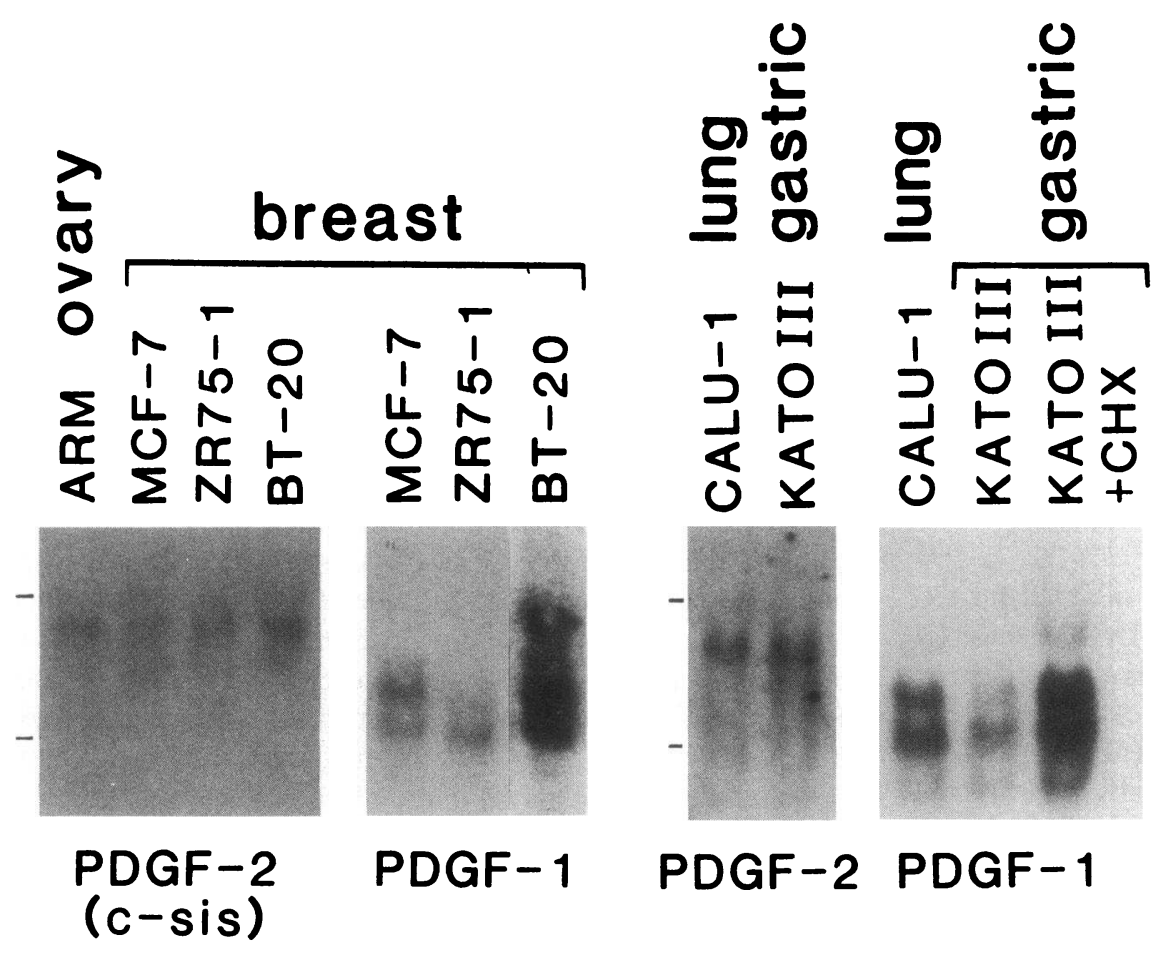

Figure 1. Expression of PDGF-1 and PDGF-2/c-sis mRNA in human breast, lung, and gastric carcinoma cells. Total cellular RNA $(20 \mu \mathrm{g})$ was analyzed for PDGF-1 and PDGF-2 transcripts using the PDGF-1 and PDGF-2 cDNA probes. One cell line (KATO III) was also exposed to $10 \mu \mathrm{g} / \mathrm{ml} \mathrm{CHX}$ for $1 \mathrm{~h}$ before RNA extraction. lung cancer cell lines (A549 and CALU-1); two colon carcinoma cell lines (COLO 201 and COLO 205); and one gastric carcinoma cell line (KATO III). The ovarian cell lines were provided by Dr. R. Knapp, Brigham and Women's Hospital, Boston, MA (21); all other cell lines were obtained from the American Type Culture Collection (ATCC, Rockville, MD).

$R N A$ analysis. Total cellular RNA ( $20 \mu \mathrm{g})$ prepared from each cell line was analyzed by the Northern blot method as described (22). DNA probes included the 2-kb Bam $\mathrm{Hl}$ fragment of the human c-sis gene purified from the pSM1 plasmid (23), the 1.3-kb Eco R1 insert of the human PDGF-1 chain gene (5), and the pm PDGF rec - Hinc II plasmid containing a 1.1-kb Hinc II insert of the mouse PDGF receptor CDNA (24).

PDGF and PDGF antibodies. PDGF was purified from human platelets and labeled with ${ }^{125} \mathrm{I}$ by the chloramine $\mathrm{T}$ method, using Iodobeads (Pierce Chemical Co., Rockford, IL), to a specific activity of $15,000-20,000 \mathrm{cmp} / \mathrm{ng}$ as described (25). A rabbit antibody to PDGF was prepared in our laboratory as described (25). IgG fractions of rabbit and goat antibody to authentic PDGF were purchased from R \& D Systems, Inc. (Minneapolis, MN) and Collaborative Research, Inc. (Waltham, MA).

Immunoprecipitation of PDGF-like proteins. Media conditioned by metabolically labeled epithelial cells were analyzed by immunoprecipitation as described (25). Briefly, cells growing as monolayers in T-75 flasks were labeled with $250 \mu \mathrm{Ci} / \mathrm{ml}\left[{ }^{35} \mathrm{~S}\right]$ cysteine (specific activity $>1,000 \mathrm{Ci} / \mathrm{mmol}$; Amersham Corp., Arlington Heights, IL) in $6 \mathrm{ml}$ of cysteine-free/serum-free medium for $18-20 \mathrm{~h}$ at $37^{\circ} \mathrm{C}$. Immunoprecipitates were analyzed under nonreducing and reducing conditions on SDS-16\% acrylamide slab gels followed by fluorography and exposure to $x$-ray films. The specificity of the proteins recognized by anti-PDGF was tested in samples treated with normal serum and/or anti-PDGF in presence of excess (500 ng) authentic PDGF (competition experiment).

Assay for mitogenic activity. Growth-promoting activity of cellconditioned media (CM) was tested as described (25). Briefly, $10 \mathrm{ml}$ of serum-free media conditioned for $24 \mathrm{~h}$ by confluent cultures of epithelial tumor cells $\left(7 \times 10^{6}\right.$ cells) were collected, clarified of particulate material by centrifugation, heated at $100^{\circ} \mathrm{C}$ for $10 \mathrm{~min}$, freeze-dried, resuspended in a small volume of $0.15 \mathrm{M} \mathrm{NaCl}$, and then dialyzed overnight at $4^{\circ} \mathrm{C}$, against $0.15 \mathrm{M} \mathrm{NaCl}$. The final volume of the dialyzed material was adjusted to $2 \mathrm{ml}$ by addition of $0.15 \mathrm{M} \mathrm{NaCl}$. Aliquots of $\mathrm{CM}$ were then tested for their ability to stimulate $\left[{ }^{3} \mathrm{H}\right]-$ thymidine incorporation into quiescent BALB-c/3T3 cells.

Assay for PDGF receptor competing activity. PDGF receptor competing activity in $\mathrm{CM}$ was detected and measured by its ability to competitively inhibit binding of ${ }^{125}$ I-PDGF to confluent cultures of BALB-c/3T3 fibroblasts as described (25). Binding studies with ${ }^{125} \mathrm{I}-$ PDGF were carried out at $4^{\circ} \mathrm{C}$ in cold binding medium (Dulbecco's PBS and $1 \%$ HSA) with or without increasing concentrations of unlabeled PDGF or concentrated CM. The cells were rinsed thoroughly after a 3-h incubation at $4^{\circ} \mathrm{C}$. Cell-bound ${ }^{125} \mathrm{I}$-PDGF was then extracted with warm $1 \%$ SDS and counted in a gamma scintillation counter.

A similar procedure was used to estimate the amount of PDGF receptors on the surface of epithelial cells. Binding studies were carried out at $4^{\circ} \mathrm{C}$ for $3 \mathrm{~h}$ using ${ }^{125} \mathrm{I}-\mathrm{PDGF}$ in the absence or presence of a 25-fold excess of unlabeled PDGF. Cell-associated radioactivity was measured as described above. To assay for the presence of occupied PDGF receptors, the experiments were repeated as described (25) after the cells were preincubated with the polyanion suramin ( $1 \mathrm{mM})$, a drug known to dissociate PDGF from high-affinity binding sites $(26,27)$.

\section{Results}

Malignant epithelial cells express PDGF-1 and sis/PDGF-2 $m R N A s$. RNA prepared from the 12 malignant epithelial cell lines was analyzed for the presence of PDGF-1- and PDGF-2related transcripts (Figs. 1 and 2). PDGF-1 mRNA was detected in each of these cell lines. The sizes of these PDGF-1 transcripts, $(2.8,2.3$, and $1.9 \mathrm{~kb})$, were similar to those reported for malignant human cells (5). A 4.2-kb PDGF-2 (c-sis) transcript was also detected in breast (three of three), lung (two of two), gastric (one of one), and ovarian (three of four) cells, but not in the two colon carcinoma cell lines. As others have described in macrophages (28), a minor 2.8-kb PDGF-2 mRNA species was also detected in one ovarian cell line 


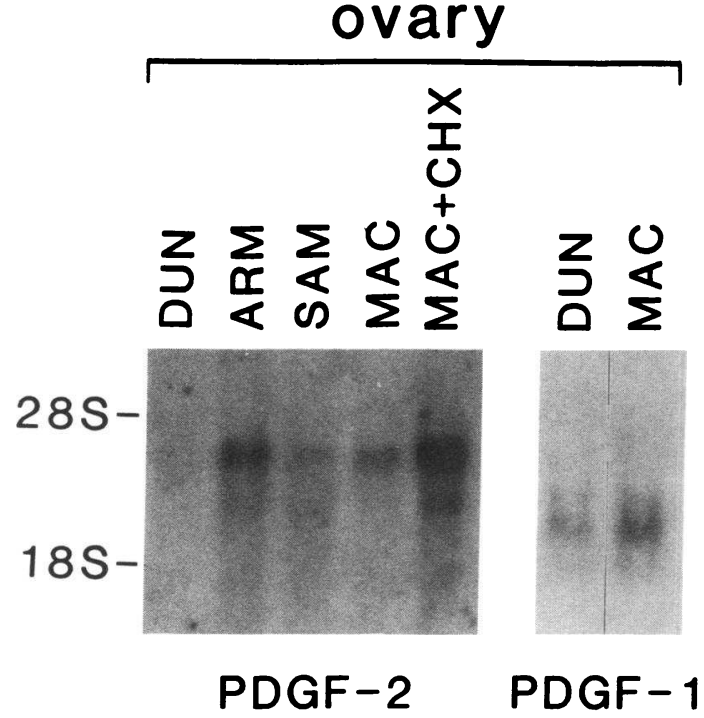

Figure 2. Expression of PDGF-1 and PDGF-2/c-sis mRNA in human ovarian carcinoma cells. Total cellular RNA $(20 \mu \mathrm{g})$ was analyzed for PDGF-1 and PDGF-2 transcripts using the PDGF-1 and PDGF-2 cDNA probes. One cell line (MAC) was also exposed to 10 $\mu \mathrm{g} / \mathrm{ml} \mathrm{CHX}$ for $1 \mathrm{~h}$ before RNA extraction.

(ARM, Fig. 2) and in the MCF-7 breast cells after polyA selection (data not shown). The levels of both PDGF-1 and PDGF-2 transcripts increased when gastric or ovarian cells were treated with cycloheximide $(\mathrm{CHX})$, an inhibitor of protein synthesis (Figs. 1 and 2); similar results were found when breast- or lung-derived cells were exposed to $\mathrm{CHX}$ (data not shown). These findings suggested that the synthesis of a labile protein was responsible for regulating levels of both PDGF-1 and PDGF-2 mRNA.

PDGF-like proteins produced by malignant epithelial cell lines are structurally different. Metabolic labeling studies were performed with $\left[{ }^{35}\right.$ S]cysteine to study the PDGF-like molecules constitutively secreted into the medium by the various epithelial cell lines. Media conditioned by malignant cells of breast, lung, and gastric origin contained $30-$ and $32-\mathrm{kD}$ proteins that were immunoprecipitated by antiserum to PDGF under nonreducing conditions (Figs. 3 and 4). Under reducing conditions, the PDGF-like proteins were converted to their monomeric forms of 15 and $16 \mathrm{kD}$. Precipitation of the 30-32and $15-16-\mathrm{kD}$ proteins by anti-PDGF was prevented in the presence of excess PDGF. Furthermore, these proteins were not precipitated by normal serum. In contrast, PDGF-like proteins were undetectable by immunoprecipitation with anti-PDGF in media conditioned by the colon carcinoma cells (Fig. 4). Immunoprecipitation of COLO 205 cell lysates also resulted in undetectable PDGF-like proteins (gels not shown), thus suggesting that these proteins were not sequestered within the cells. As previously reported $(20,22)$, proteins of higher molecular weight ( $>40 \mathrm{kD}$ ) were also immunoprecipitated by the antibody to PDGF and were competed by an excess of cold PDGF (Figs. 3 and 4). These proteins were better resolved on $8 \%$ acrylamide gels, and their molecular weights were estimated to be $45,70,115$, and $185 \mathrm{kD}$ under reducing conditions (gels not shown).

In contrast to the findings with breast, lung, and gastric carcinoma cell lines, a protein of $\sim 14 \mathrm{kD}$ was immunoprecipitated by anti-PDGF in media conditioned by each of the four metabolically labeled ovarian carcinoma cell lines (Fig. 5). A 16-kD PDGF-like protein was also detected in the conditioned medium from two (ARM and SAM) of the ovarian cell lines (Fig. 5). Immunoprecipitation of the 14-16-kD proteins was competitively inhibited by an excess of PDGF. The mobility of these proteins did not change on SDS gels after reduction (results not shown).

PDGF-like molecules secreted by epithelial cells are biologically active. Media conditioned by various carcinoma cell lines were assayed for their ability to stimulate the uptake of $\left[{ }^{3} \mathrm{H}\right]$ thymidine by cultured $3 \mathrm{~T} 3$ fibroblasts. As listed in Table I, detectable amounts of mitogenic activity were found in all 10 of the tested CM. Heat treatment $\left(100^{\circ} \mathrm{C}\right.$ for $\left.10 \mathrm{~min}\right)$ of the $\mathrm{CM}$ did not affect mitogenic activity, whereas this activity decreased after reduction of CM with mercaptoethanol or after preincubation of the CM with $100 \mathrm{ng} / \mathrm{ml}$ anti-PDGF IgG (Table I). Altogether, these results suggested that a significant proportion of the mitogenic activity detected in the $C M$ of these carcinoma cells was related to the presence of PDGF-like proteins.

$P D G F$ receptor competing activity. CM derived from five epithelial cell lines (one lung, one gastric, one breast, and two ovarian lines) were analyzed for their ability to compete for ${ }^{125}$ I-PDGF binding to the PDGF receptor on 3T3 fibroblasts. As shown in Fig. 6, all CM from the tested lines inhibited

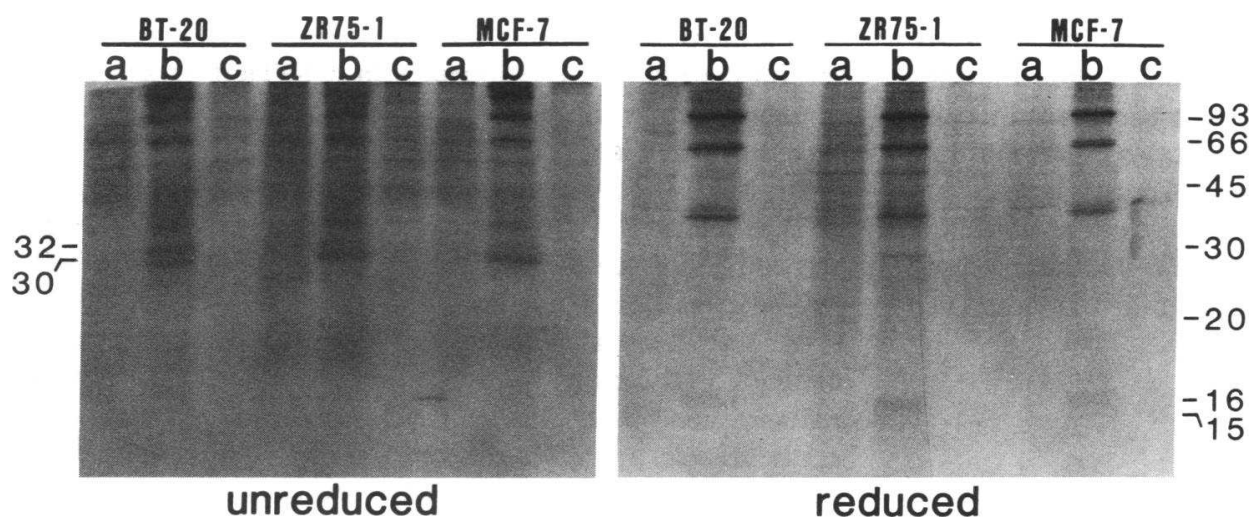

BREAST
Figure 3. Immunoprecipitation of PDGF-like proteins from media of human malignant breast epithelial cells. Media prepared from metabolically labeled cells (BT-20, ZR75-1, and MCF-7), was immunoprecipitated with anti-PDGF. The immunoprecipitates were analyzed by SDS-PAGE under unreduced or reduced conditions. Immunoprecipitation was carried out with normal serum (lane $A$ ), antiserum to PDGF (lane $B$ ), and antiserum to PDGF in presence of excess PDGF (competition experiment) (lane $C$ ). 

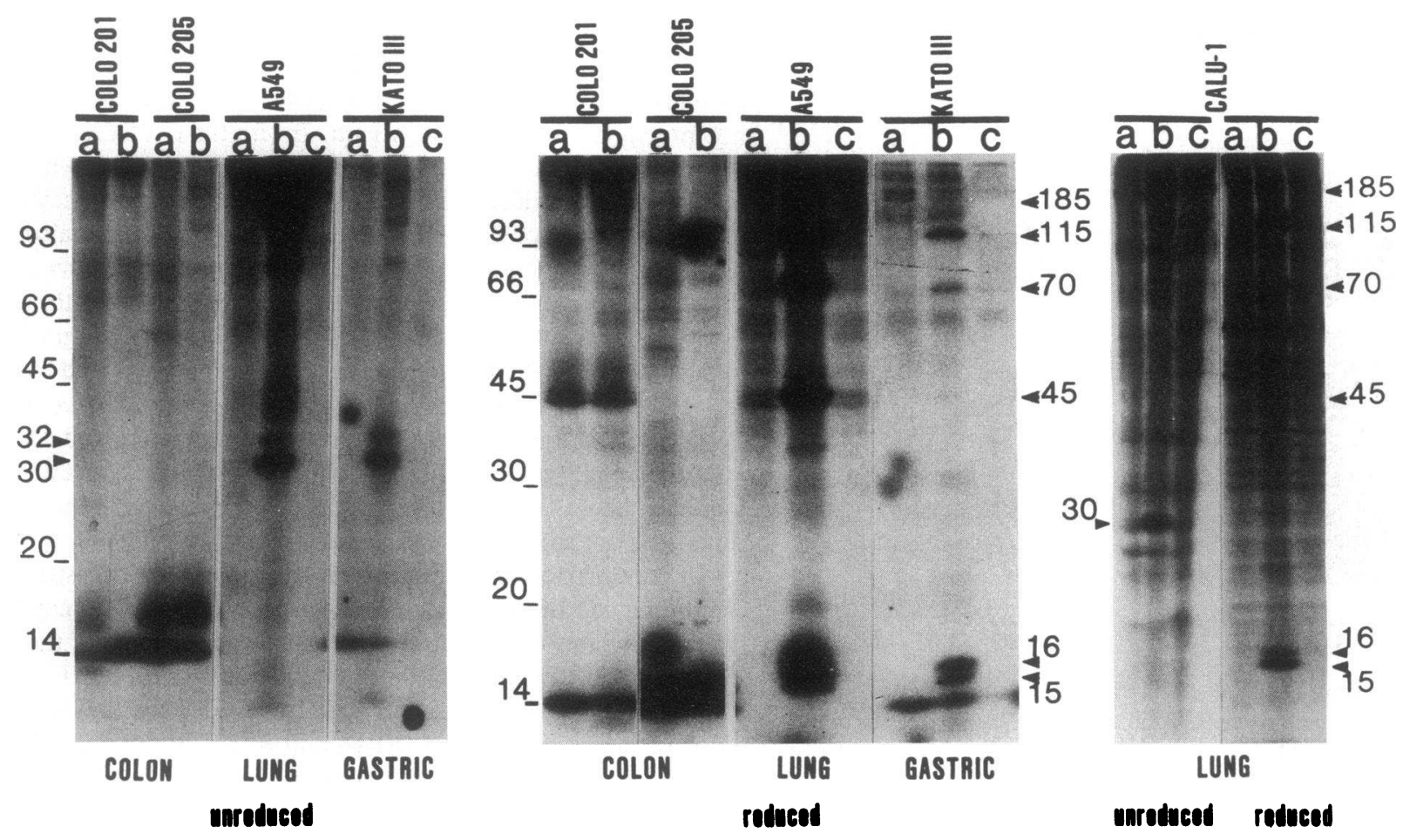

Figure 4. Immunoprecipitation of PDGF-like proteins from media of human malignant epithelial cells of colon, lung, and gastric origin. Media from metabolically labeled cells of colon (COLO-201 and COLO-205), lung (A-549 and CALU-I), and gastric (KATO III) origin were analyzed as described in the legend to Fig. 3. Lanes $A, B$, and $C$ are as described in Fig. 3.

binding of ${ }^{125}$ I-PDGF to fibroblasts in a dose-dependent manner. On the basis of radiocompetition studies using purified PDGF, we estimate the concentration of PDGF in the unconcentrated CM of these malignant epithelial cells to be 1-6 ng PDGF/ml.

Epithelial cells do not display PDGF receptors. Specific ${ }^{125}$ I-PDGF binding to malignant epithelial cell lines was compared with the binding detected in 3T3 fibroblasts. When incubated with $1 \mathrm{ng} / \mathrm{ml}{ }^{125} \mathrm{I}$-PDGF, $11 \%$ of the radioactivity was found to bind to 3 T 3 cells (Table II). In contrast, only $1.1-1.9 \%$ of the labeled PDGF bound to six of the malignant epithelial cells. This low level of binding was considered nonspecific since it did not decrease after incubation of these cells with an excess of cold PDGF and was comparable to the amount of binding obtained after incubation of 3T3 cells with an excess of cold PDGF $(50 \mathrm{ng} / \mathrm{ml})$. Similar low levels of ${ }^{125} \mathrm{I}-$ PDGF binding were obtained when three cell lines (BT-20, A549, and KATO III) were pretreated with suramin. This drug dissociates PDGF bound to cell membranes and thus unmasks PDGF receptors $(26,27)$. The absence of a significant increase in ${ }^{125}$ I-PDGF binding after suramin treatment provided further evidence that these malignant epithelial cells lack detectable PDGF receptors. Finally, we were unable to detect mRNA for the PDGF receptor gene in 10 epithelial cell lines, whereas these transcripts were present in $\mathbf{2}$ different clones of a mouse fibroblast cell line (Fig. 7).

\section{Discussion}

The present results demonstrate that PDGF-1 and sis/PDGF2 mRNAs are expressed in human malignant cells derived from breast, ovarian, lung, and gastric epithelium. A previous study demonstrated the presence of both transcripts in human sarcoma cell lines (5), whereas subsequent work detected only PDGF-1 mRNA in three human melanoma cell lines (29). The detection of PDGF-2 transcripts in malignant epithelial cells, however, is in contrast to the findings of a previous study (30). Although the basis for this discrepancy is unclear, our results clearly demonstrate that expression of both the PDGF-1 and PDGF-2 genes is widespread among human carcinoma cell lines. Our findings also suggest that the expression of both genes is regulated by protein(s) with a short half-life. Similar results were obtained in human macrophages exposed to CHX (29a) suggesting that both genes were under similar control(s) in cells of mesenchymal or epithelial origin.

We also demonstrate that human malignant epithelial cells of diverse tissue origin produce biologically active PDGF-like proteins. These proteins were characterized as being PDGFlike on the basis of antigenic similarities with authentic PDGF and on their ability to compete with ${ }^{125}$ I-PDGF in a dose-dependent manner for high-affinity binding receptors. The estimated concentration of PDGF-like material in the conditioned media of these epithelial cells ranges from 1 to $6 \mathrm{ng} / \mathrm{ml}$.

The secreted PDGF-like species differ in molecular weight according to tissue origin of the epithelial tumor cells. PDGFlike proteins from malignant cells of breast, lung, and gastric origin were detectable as 30 - and $32-\mathrm{kD}$ species under nonreducing conditions and as subunits of 15- and 16-kD under reducing conditions. The PDGF-like proteins from malignant epithelial cells are similar to the PDGF-like proteins produced by several other human malignant cell lines of mesenchymal origin (18-20) and human $T$ lymphocytes infected with the human T cell lymphotropic viruses, HTLV-I and II (31). Also, 


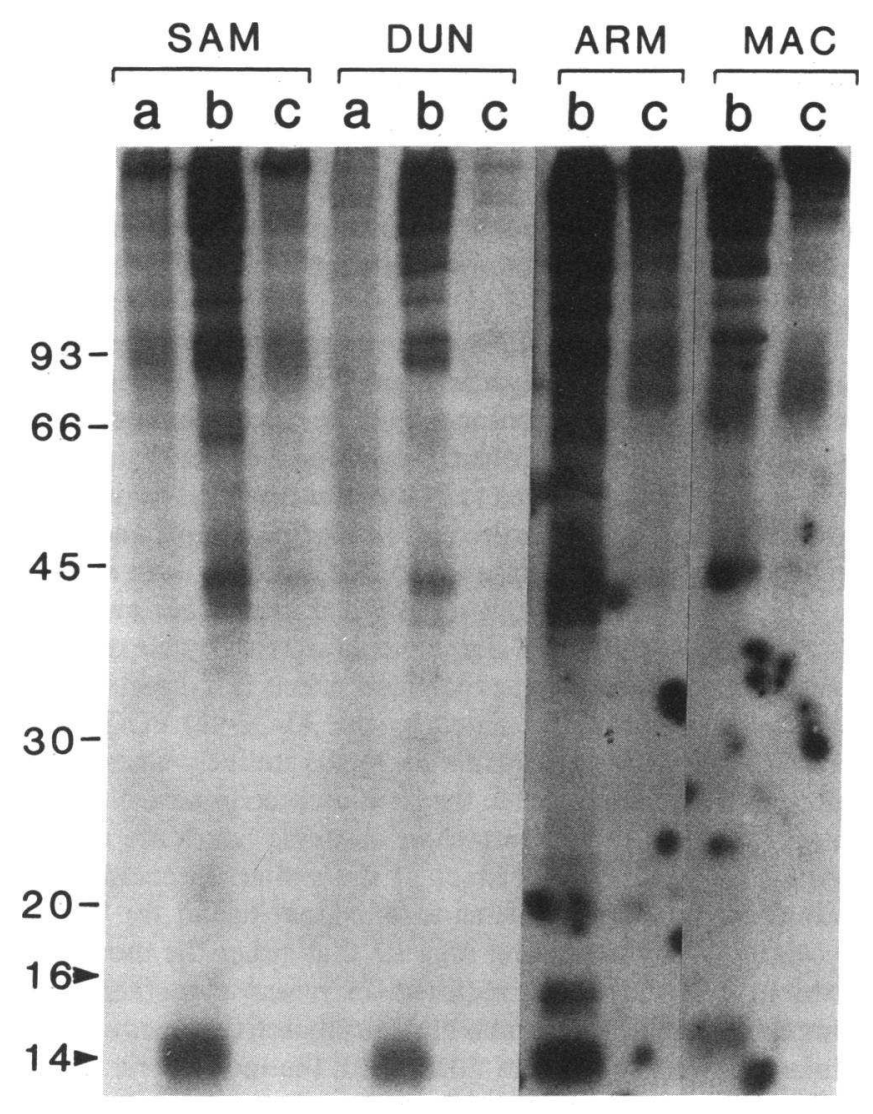

unreduced

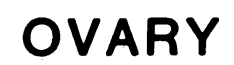

Figure 5. Immunoprecipitation of PDGF-like proteins from media of human malignant epithelial ovarian cells. Media prepared from metabolically labeled malignant ovarian cells were immunoprecipitated with anti-PDGF, and the immunoprecipitates were analyzed under nonreducing conditions. Immunoprecipitation was carried out with normal serum (lanes $A$ ), antiserum to PDGF (lanes $B$ ), and antiserum to PDGF in presence of excess PDGF (lanes $C$ ).

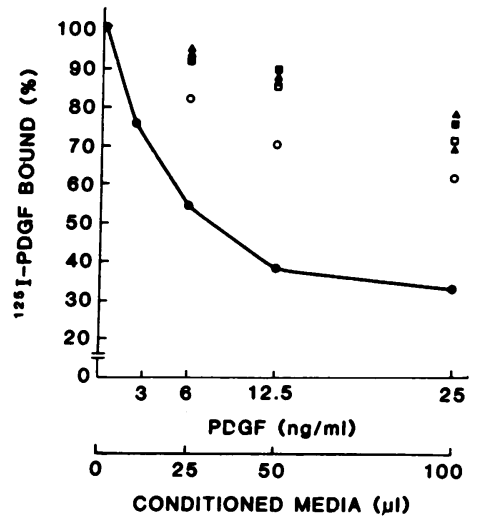

Figure 6. Competition of 125I-PDGF binding to BALB-c/3T3 fibroblasts by CM from human epithelial cell lines. Increasing amounts of fivefold concentrated $C M(25,50$, and $100 \mu l)$ from five different cell lines were studied by the PDGF receptor competition assay. 3T3 cells in the absence of $\mathrm{CM}$ bound 3 $\times 10^{3} \mathrm{cpm} / 1.5 \times 10^{5}$ cells after incubation with $20,000 \mathrm{cpm}{ }^{125}$ I-PDGF $(0 \%$ displacement). Specific

binding was calculated by subtracting nonspecific binding $(<10 \%)$. Each point represents the mean of triplicate samples of two experiments (SD < 5\%, $n=6$ ). By extrapolation to the standard curve the estimated amount of PDGF-like material in unconcentrated CM was estimated to be $1-6 \mathrm{ng} / \mathrm{ml}$. $\bullet$, standard curve (competing activity of unlabeled PDGF); $\triangle$, DUN (ovary); «, KATO III (gastric); 口, A549 (lung); $\triangle$, ARM (ovary); O, ZR75-1 (breast).

a 31-kD PDGF-like protein with mitogenic activity has been detected in two human breast carcinoma cell lines (32-34). In contrast, the major PDGF-like species detectable in tumor cells of ovarian origin had molecular masses of 14-16 kD. Furthermore, biologically active PDGF-like proteins secreted by macrophages have molecular masses of $12-13.5 \mathrm{kD}$, which are unchanged after reduction (35). Although the low-molecular weight PDGF-like species detected in ovarian cells and in macrophages share similar characteristics, whether they are in fact identical proteins remains unclear. Further, high-molecular weight PDGF-related proteins of $45-185 \mathrm{kD}$ were also detected on reducing gels. Similar proteins have been observed in human glioblastoma, fibrosarcoma, and HTLV-infected T cell lines $(20,31)$. However, these proteins are not mitogenic for fibroblasts. We have recently demonstrated that complexes of PDGF and the complement component 3 (C3) are coprecipitated during the immunoprecipitation reaction (Pantazis, P.,

Table I. Mitogenic Activity of Media Conditioned by Human Malignant Epithelial Cells

\begin{tabular}{|c|c|c|c|c|c|c|c|c|c|c|}
\hline & \multicolumn{4}{|c|}{ Ovary } & \multicolumn{3}{|c|}{ Breast } & \multicolumn{2}{|c|}{ Lung } & \multirow{2}{*}{$\frac{\text { Gastric }}{\text { KATO-III }}$} \\
\hline & SAM & ARM & DUN & MAC & BT-20 & MCF-7 & ZR75-1 & A459 & CALU-I & \\
\hline \multicolumn{11}{|l|}{ Volume added } \\
\hline $5 \mu \mathrm{l}$ & 0 & 0 & 0 & 0 & 85 & 12 & 20 & 0 & 10 & 0 \\
\hline $25 \mu \mathrm{l}$ & 48 & 64 & 32 & 25 & 230 & 39 & 100 & 22 & 118 & 52 \\
\hline $50 \mu 1$ & 66 & 129 & 50 & 89 & 330 & 73 & 116 & 165 & 334 & 143 \\
\hline $50 \mu \mathrm{l}$ (reduced) & 0 & 64 & 0 & 32 & 45 & 0 & 0 & 9 & 1 & 26 \\
\hline $50 \mu l+$ anti-PDGF IgG & NT & 39 & NT & NT & 28 & NT & 33 & NT & NT & 19 \\
\hline
\end{tabular}

Serum-free CM were harvested from various cell lines and concentrated 10-fold and increasing volumes of concentrated $\mathrm{CM}(5,25$, and $50 \mu \mathrm{l})$ were analyzed for growth-promoting activity in cultures of $3 \mathrm{~T} 3$ fibroblasts. Results are expressed as the ratio of $\left[{ }^{3} \mathrm{H}\right]$ thymidine incorporation in 3T3 cells treated with each CM to incorporation by untreated cells. Parallel cultures were incubated with either $50 \mu l$ reduced $C M$ or $50 \mu l$ unreduced CM to which anti-PDGF IgG had been added at a final concentration of $100 \mathrm{ng} / \mathrm{ml}$. Background (0\%) mitogenic activity was determined by $\left[{ }^{3} \mathrm{H}\right]$ thymidine incorporation in untreated $3 \mathrm{~T} 3$ cultures and was $37,000 \mathrm{cpm} / 10^{6}$ cells. Exposure to 1 and $5 \%$ FCS resulted in 200 and $400 \%$ increases in mitogenic activity, respectively. Results represent the mean values from triplicates of at least three experiments from each cell line (SD $\leq 10 \%)$. NT, not tested. 
Table II. Binding of ${ }^{125}$ I-PDGF to Human

Malignant Epithelial Cells

\begin{tabular}{lcc}
\hline \multicolumn{1}{c}{ Cell line and origin } & $\begin{array}{c}\text { Percent } \\
\text { 125I-PDGF } \\
\text { bound }\end{array}$ & $\begin{array}{c}\text { Percent } \\
\text { in presence of excess } \\
\text { cold PDGF }\end{array}$ \\
\hline BALB-c/3T3(fibroblast) & 11.0 & 1.8 \\
ARM (ovary) & 1.2 & 1.2 \\
DUN (ovary) & 1.3 & 1.2 \\
BT-20 (breast) & $1.6(1.0)$ & $1.5(1.2)$ \\
A549 (lung) & $1.9(1.3)$ & $1.8(1.1)$ \\
CALU-I (lung) & 1.2 & 1.1 \\
KATO III (gastric) & $1.2(0.9)$ & $1.1(0.6)$ \\
& & \\
\hline
\end{tabular}

Results are expressed as the percent of total added ${ }^{125}$ I-PDGF ( 2 ng $40,000 \mathrm{cpm}$ ) that bound to the cells. In parallel cultures, unlabeled PDGF was added in excess (competition experiment) to a final concentration of $100 \mathrm{ng} / \mathrm{ml}$. Values in parentheses indicate the percent of ${ }^{125}$ I-PDGF bound after pretreatment of cells with suramin. Values are calculated from the mean of triplicate determinations using cultures from two independent experiments (SD $\leq 10 \%$ ).

et al., unpublished results). Whereas further studies have demonstrated that the $45-$ to $185-\mathrm{kD}$ species represent precursor, mature, and processed $\mathrm{C} 3$, these results are beyond the scope of this work.

Differences in molecular weight of PDGF-like proteins produced by various cell types may be secondary to differences in gene utilization, RNA transcription, or protein processing. The presence of more than one sis-related gene seems unlikely, since they would have been detected during chromosomal gene localization or during genomic cloning of the c-sis gene. Furthermore, no gross rearrangement of the PDGF- 1 and PDGF-2 genes were detected when DNA from MCF-7 cells was compared by Southern analysis with DNA from DUN, MAC, and SAM ovarian cells (data not shown). The use of a cryptic promoter, early polyadenylation signals, or alternative splicing are various mechanisms that can generate protein diversity from a single gene. Similar 4.2-kb c-sis transcripts were detected in these human epithelial tumor cells, irrespective of the size of the secreted PDGF-like protein. However, small differences in mRNA transcripts, such as the loss of 100-200 $\mathrm{bp}$, the size of any of the seven coding exons of the c-sis gene (36), would not have been detected by Northern analysis. Further studies, including S1 nuclease mapping, should provide information about the existence of possible mechanisms like alternative splicing that could generate diverse PDGF protein species with specific functions in malignant cells of different tissue origin.

Evidence that the PDGF-like proteins secreted by the carcinoma cells are biologically active was provided by the demonstration that media conditioned by these cells stimulate DNA synthesis of quiescent fibroblasts. Additional evidence that this mitogenic activity is related to PDGF was provided by demonstrating heat stability, sensitivity to reducing agents, and neutralization by specific antiserum to PDGF. Since these experiments were performed with conditioned media, our evidence that the 14-16-kD PDGF-like proteins secreted by the ovarian cells are responsible for the biological effects is indirect. These effects thus could be mediated by the 30-32-kD PDGF-like proteins, although this possibility seems unlikely since these proteins are undetectable in the immunoprecipitates. A recent study has revealed that interchain disulfide bonds are not essential for $\mathrm{p} 28^{\mathrm{sis}}$, the product of the simian sarcoma virus transforming gene, to act as a functional ligand for PDGF receptor (37). This finding suggests that either the monomer exhibits a conformation required for receptor interaction or that the molecule can form a biologically active noncovalently linked dimer structure. In this regard, the monomeric 12-kD PDGF-like protein secreted by macrophages competes with ${ }^{125}$ I-PDGF for binding to the PDGF receptor and displays mitogenic activity (35). In view of these results, the 14-16-kD monomeric PDGF-like proteins secreted by the ovarian cells are probably responsible for PDGF-like biologic activities and competition with authentic PDGF for receptor binding.

In our study, malignant cells of breast, lung, gastric, and ovarian origin had undetectable levels of PDGF receptors. Since these cells also express PDGF-related proteins, the PDGF-receptors may have been down-regulated by the endogenously produced PDGF. Suramin, which dissociates PDGF from its receptor, has been used successfully to unmask PDGF receptors $(26,27)$ PDGF producer. Use of this drug in our study failed to reveal the presence of occupied PDGF recep-

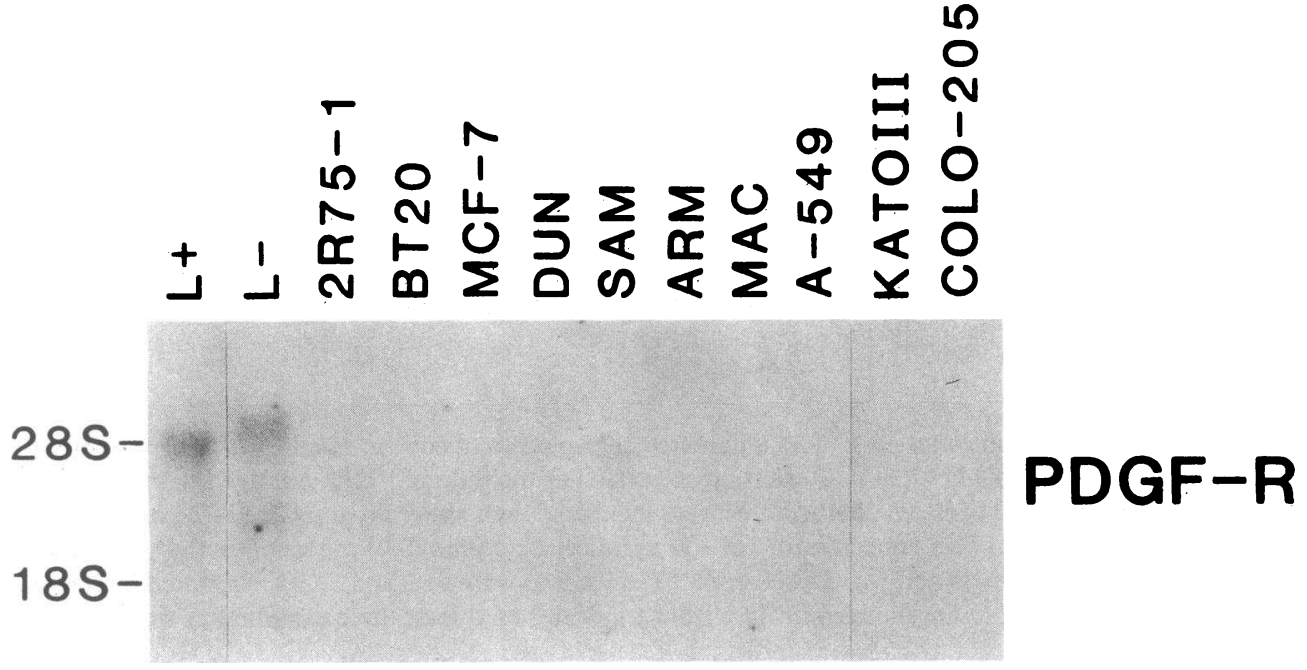

Figure 7. Expression of PDGF receptor in mouse fibroblasts and in human epithelial cell lines. Total cellular RNA $(20 \mu \mathrm{g})$ was analyzed for the presence of PDGF receptor mRNA using a PDGF receptor CDNA probe in 2 different clones of the mouse fibroblast $\mathrm{L}$ cell line $(\mathrm{L}+, \mathrm{L}-)$ and in 10 different human epithelial cell lines. 
tors. The lack of PDGF receptors in epithelial cells was consistent with the absence of PDGF receptor mRNA in these cells. This finding is in agreement with the lack of mitogenic response of carcinoma cells to PDGF (38). None of the six human malignant epithelial cell lines derived from lung, thyroid, epidermis, and neuroblastoma studied previously had PDGF receptors (39). The presence of high-affinity cell surface receptors for PDGF thus seems to be limited to mesenchymederived cells. Further, it has been recently reported that there is more than one PDGF receptor phenotype (40). The three different PDGF protein isoforms thus should be tested in binding studies to definitively evaluate the presence of PDGF receptors on these cells.

PDGF may stimulate growth by an autocrine mechanism in mesenchyme-derived cells (19). In contrast, PDGF apparently acts in a paracrine fashion in epithelial cells. PDGF is a mitogenic factor for fibroblasts and smooth muscle cells, and is a potent chemotactic factor for neutrophils (41), monocytes (42), and smooth muscle cells and fibroblasts $(1,2)$. The fibrosis and inflammatory reactions seen in tumors of epithelial origin thus may be mediated by PDGF-like molecules secreted by the malignant epithelial cells. Alternatively, many of the biological effects of PDGF-like proteins secreted by the epithelial cells may be mediated through the activation of fibroblasts. In this regard, PDGF has been shown to induce fibroblasts to secrete growth factors such as somatomedin C, a potent fibroblast growth factor (43). Additionally, the fibroblast is a source of the colony-stimulating factor, CSF-1 (44), which is essential for the growth and differentiation of monocytic cells. The fibrosis, neovascularization, and inflammation seen in epithelial tumors thus may be either related to the direct effect of PDGF on specific target cells or secondary to the release of diverse growth factors by the PDGF activated fibroblasts. Since our study was performed on cultured cells derived from tumors and not on primary tissues, further studies are needed to determine: (a) if PDGF production by malignant epithelial cells occurs in vivo, $(b)$ if PDGF secretion is a physiological event in normal epithelial cells, and (c) if PDGF production can be regulated in these cells by specific ligand-receptor interactions.

\section{Acknowledgments}

We thank C.-H. Heldin for the gift of the PDGF-1 plasmid, A. Ullrich for the PDGF-receptor plasmid, R. Knapp, P. Maimonis, C. Rodriguez, and D. Spriggs for providing cell lines, A. S. Goustin for helpful discussions, and D. Wilkinson and $\mathrm{H}$. Hourihan for manuscript preparation.

This work was supported in part by Public Health Service grants CA-38784 (to Dr. Pantazis), CA-30101, and HL-29583 (to Dr. Antoniades) from the National Institutes of Health, and by the Council for Tobacco Research, USA (to Dr. Antoniades). Dr. Sariban received a North Atlantic Treaty Organization fellowship and Dr. Kufe received a Burroughs-Wellcome Clinical Pharmacology Scholar Award.

\section{References}

1. Ross, R., E. W. Raines, and D. F. Bowen-Pope. 1986. The biology of platelet-derived growth factor. Cell. 46:155-169.

2. Antoniades, H. N., P. Pantazis, and A. J. Owen. 1987. Human platelet-derived growth factor and the sis/PDGF-2 gene. In Oncogenes, Genes and Growth Factors. G. Guroff, editor. John Wiley \& Sons, Inc., New York. 1-40.
3. Dalla-Favera, R., R. Gallo, C. Giallongo, and C. Croce. 1982. Chromosomal localization of the human homolog (c-sis) of the simian sarcoma virus onc gene. Science (Wash. DC). 218:686-688.

4. Swan, D. C., O. W. McBride, K. C. Robbins, D. A. Keithly, E. P. Reddy, and S. A. Aaronson. 1982. Chromosomal mapping of the simian sarcoma virus onc gene analogue in human cells. Proc. Natl. Acad. Sci. USA. 79:4691-4695.

5. Betsholtz, C., A. Johnson, C.-H. Heldin, B. Westermark, P. Lind, M. S. Urdea, R. Eddy, T. B. Shows, K. Philpott, A. Mellor, T. J. Knott, and J. Scott. 1986. cDNA sequence and chromosomal localization of human platelet-derived growth factor A-chain and its expression in tumor cell lines. Nature (Lond.). 320:695-699.

6. Robbins, K. C., H. Antoniades, S. G. Devare, M. W. Hunkapiller, and S. A. Aaronson. 1983. Structural and immunological similarities between simian sarcoma virus gene and human platelet-derived growth factor. Nature (Lond.). 305:605-608.

7. Antoniades, H. N. and M. W. Hunkapiller. 1983. Human platelet-derived growth factor (PDGF): amino terminal amino acid sequence. Science (Wash. DC). 220:963-965.

8. Johnsson, A., C.-H. Heldin, A. Wasteson, A. Westermark, T. F. Deuel, J. S. Juang, P. H. Seeberg, E. Gray, A. Ullrich, G. Scrace, P. Stroobant, and M. D. Waterfield. 1984. The c-sis gene encodes a precursor of the B chain of platelet-derived growth factor. $E M B O$ (Eur. Mol. Biol. Organ.) J. 3:921-928.

9. Heldin, C.-H., A. Johnsson, S. Wennergren, C. Wernstedt, C. Betsholtz, and B. Westermark. 1986. A human osteosarcoma cell line secretes a growth factor structurally related to a homodimer of PDGF A-chains. Nature (Lond.). 319:511-514.

10. Berk, B. C., R. W. Alexander, T. A. Brock, M. A. Gimbrone, and C. R. Webb. 1986. Vasoconstriction: a new activity for plateletderived growth factor. Science (Wash. DC). 232:87-90.

11. Narayanan, A. S., and R. C. Page. 1983. Biosynthesis and regulation of type $\mathrm{V}$ collagen in diploid human fibroblasts. $J$. Biol. Chem. 258:11694-11699.

12. Bauer, E. A., T. W. Cooper, J. S. Huang, J. Altman, and T. F. Deuel. 1985. Stimulation of in vitro human skin collagenase expression by platelet-derived growth factor. Proc. Natl. Acad. Sci. USA. 82:4132-4136.

13. Chua, C. C., D. E. Geiman, G. H. Keller, and R. L. Ladda. 1985. Induction of collagenase secretion in human fibroblast cultures by growth promoting factors. J. Biol. Chem. 260:5213-5216.

14. Collins, T., D. Ginsburg, J. M. Boss, S. M. Orkin, and J. S. Pober. 1985. Cultured human endothelial cells express platelet-derived growth factor chain 2: cDNA cloning and structural analysis. Nature (Lond.). 316:748-750.

15. Sitaras, N., E. Sariban, P. Pantazis, B. Zetter, and H. N. Antoniades. 1987. Human iliac artery endothelial cells express both genes encoding the chains of platelet-derived growth factor (PDGF) and synthesize PDGF-like mitogen. J. Cell. Physiol. 132:376-380.

16. Seifert, R. A., S. M. Schwartz, and D. F. Bowen-Pope. 1984. Developmentally regulated production of platelet-derived growth factor-like molecules. Nature (Lond.). 311:669-671.

17. Goustin, A. S., C. Betsholtz, S. Pfeifer-Ohlsson, H. Persson, J. Rydnert, M. Bywater, G. Holmgren, C. H. Heldin, B. Westermark, and $\mathrm{R}$. Ohlsson. 1985. Coexpression of the sis and myc proto-oncogenes in developing human placenta suggests autocrine control of trophoblast growth. Cell. 41:301-312.

18. Betsholtz, C., C.-H. Heldin, C. Nister, B. Ek, A. Wasteson, and B. Westermark. 1983. Synthesis of a PDGF-like growth factor in human glioma and sarcoma cells suggests the expression of the cellular homologue to the transforming protein of simian sarcoma virus. Biochem. Biophys. Res. Commun. 117:176-182.

19. Betsholtz, C., B. Westermark, B. Ek, and C. H. Heldin. 1984. Coexpression of a PDGF-like growth factor and PDGF receptors in a human osteosarcoma cell line: implications for autocrine receptor activation. Cell. 39:447-457.

20. Pantazis, P., P. G. Pelicci, R. Dalla-Favera, and H. N. Antoniades. 1985. Synthesis and secretion of proteins resembling platelet-de- 
rived growth factor by human glioblastoma and fibrosarcoma cells in culture. Proc. Natl. Acad. Sci. USA. 82:2404-2408.

21. Masuho, Y., M. Zalutsky, R. C. Knapp, and R. C. Bast. 1984. Interaction of monoclonal antibodies with cell surface antigens of human ovarian carcinomas. Cancer Res. 44:2813-2819.

22. Pantazis, P., E. Sariban, D. Kufe, and H. N. Antoniades. 1986. Expression of the c-sis proto-oncogene and synthesis of PDGF during human monocytic differentiation. Proc. Natl. Acad. Sci. USA. 83:6455-6459.

23. Ratner, L., S. F. Josephs, R. Jarett, M. S. Reitz, and F. WongStaal. 1985. Nucleotide sequence of transforming human c-sis DNA clones with homology to platelet-derived growth factor. Nucleic Acids Res. 13:5007-5018.

24. Yarden, Y., J. A. Escobedo, W. J. Kuang, T. L. Yang-Feng, T. O. Daniel, P. M. Tremble, E. Y. Chen, M. E. Ando, R. N. Harkins, U. Francke, V. A. Fried, A. Ullrich, and L. T. Williams. 1986. Structure of the receptor for platelet-derived growth factor helps define a family of closely related growth factor receptors. Nature (Lond.). 323:226-232.

25. Antoniades, H. N., and P. Pantazis. 1987. Structural and functional identification of platelet-derived growth factor-like proteins produced by mammalian cells. Methods Enzymol. 147:22-40.

26. Williams, L. T., P. M. Tremble, M. F. Lavin, and M. E. Sunday. 1984. PDGF receptors form a high affinity state in membrane preparations. J. Biol. Chem. 259:5287-5294.

27. Hosang, G. M. 1985. Suramin binds to platelet-derived growth factor and inhibits its biological activity. J. Cell. Biochem. 29:265-273.

28. Mornex, J.-F., Y., Martinet, K. Yamauchi, P. B. Bitterman, G. R. Grotendorst, A. Chytil-Weir, G. Martin, and R. G. Crystal. 1986. Spontaneous expression of the c-sis gene and release of a platelet-derived growth factor-like molecule by human alveolar macrophages. J. Clin. Invest. 78:61-66.

29. Westermark, B., A. Johnsson, Y. Paulson, C. Betsholtz, C.-H. Heldin, M. Heilyn, U. Rodeck, and M. Koprowski. 1986. Human melanoma cell lines of primary and metastatic origin express the genes encoding the chains of platelet-derived growth factor (PDGF) and produce a PDGF-like growth factor. Proc. Natl. Acad. Sci. USA. 83:7197-7200.

29a. Sariban, E., and D. Kufe. 1988. Expression of the platelet-derived growth factor 1 and 2 genes in human myeloid cell lines and monocytes. Cancer Res. 48:4498-4502.

30. Eva, A., K. S. Robbins, P. R. Anderson, A. Srinivasan, S. R. Tronick, E. P. Reddy, N. W. Ellnore, A. T. Galen, J. A. Lautenberger, T. S. Papas, E. H. Westin, F. Wong-Staal, R. C. Gallo, and S. A. Aaronson. 1982. Cellular genes analogous to retroviral onc genes are transcribed in human tumour cells. Nature (Lond.). 295:116-119.
31. Pantazis, P., E. Sariban, C. A. Bohan, H. N. Antoniades, and V. S. Kalyanaraman. 1987. Synthesis of PDGF by cultured human T cells transformed with HTLV-I and II. Oncogene. 1:285-289.

32. Rozengurt, E., J. Sinnett-Smith, and J. Taylor-Papadimitrou. 1985. Production of PDGF-like growth factor by breast cancer cell lines. Int. J. Cancer. 36:247-252.

33. Bronzert, D., P. Pantazis, H. N. Antoniades, A. Kasid, N. Davidson, R. B. Dickson, and M. E. Lippman. 1987. Synthesis and secretion of PDGF-like growth factor by human breast cancer cell lines. Proc. Natl. Acad. Sci. USA. 84:5763-5767.

34. Perez, R., C. Betsholtz, B. Westermark, and C.-H. Heldin. 1987. Frequent expression of growth factors for mesenchymal cells in human mammary carcinoma cell lines. Cancer Res. 47:3425-3429.

35. Shimokado, K., E. W. Raines, D. K. Madtes, T. B. Barret, E. P. Benditt, and R. Ross. 1985. A significant part of macrophage-derived growth factor consists of at least two forms of PDGF. Cell. 43:277-286.

36. Van den Ouweland, A. N., A. J. Roebroek, J. A. Schalken, C. A. Claesen, H. P. Bloemers, and W. J. Van de Ven. 1986. Structure and nucleotide sequence of the $5^{\prime}$ region of the human and feline c-sis proto oncogenes. Nucleic Acids Res. 14:765-778.

37. Giese, N. A., K. C. Robbins, and S. A. Aaronson. 1987. The role of individual cysteine residues in the structure and function of the v-sis gene product. Science (Wash. DC). 236:1315-1318.

38. Sitaras, N., E. Sariban, M. Bravo, P. Pantazis, and H. N. Antoniades. 1988. Constitutive production of PDGF-like proteins by human prostate carcinoma cell lines. Cancer Res. 48:1930-1935.

39. Heldin, C.-H., B. Westermark, and A. Wasteson. 1981. Specific receptors for platelet-derived growth factor on cells derived from connective tissue and glia. Proc. Natl. Acad. Sci. USA. 78:3664-3668.

40. Heldin, C.-H., G. Bäckström, A. Östman, A. Hammacher, L. Rönnstrand, K. Rubin, M. Nistér, and B. Westermark. 1988. Binding of different dimeric forms of PDGF to human fibroblasts: evidence for two separate receptor types. EMBO (Eur. Mol. Biol. Organ.) J. 7:1387-1393.

41. Tzeng, D. Y., T. F. Deuel, J. S. Huang, R. M. Senior, L. A. Boxer, and R. L. Baehner. 1984. Platelet-derived growth factor promotes polymorphonuclear leukocyte activation. Blood. 64:1123-1128.

42. Tzeng, D. Y., T. F. Deuel, J. S. Huang, and R. L. Baehner. 1985. Platelet-derived growth factor promotes human peripheral monocyte activation. Blood. 66:179-183.

43. Clemmons, D. R., L. E. Underwood, and J. J. Van Wyk. 1981. Hormonal control of immunoreactive somatomedin production by cultured human fibroblasts. J. Clin. Invest. 75:1914-1918.

44. Sieff, C. A. 1987. Hematopoetic growth factors. J. Clin. Invest. 79:1549-1557. 